\title{
Effect of Entrepreneurship Education for College Students in the Context of a Mobile Internet Environment
}

\author{
https://doi.org/10.3991/ijet.v16i20.26509 \\ Dapeng Sun ${ }^{1}$, Mengnan $\operatorname{Li}^{2}(\varpi)$ \\ ${ }^{1}$ Hebei Institute of Mechanical and Electrical Technology, Xingtai, China \\ ${ }^{2}$ North China Institute of Aerospace Engineering, Langfang, China \\ Limengnan790929@163.com
}

\begin{abstract}
College students are having a difficult time in hunting a job upon graduation. The mobile Internet helps to promote the employment of college graduates. In an environment of mobile Internet, this paper clarifies the current state of Entrepreneurship Education (EE) for college students, and discusses the effectiveness of $\mathrm{EE}$ in the context of a mobile Internet environment. The results show that: mobile Internet enriches the substance of EE courses in colleges, improves the environment of EE, facilitates the provision of $\mathrm{EE}$ for college students, makes the EE model fairer, and promotes the reform of the model. In addition, the EE platform built for college students can be broken down into three layers: a data access layer, a business logic layer, and a user interface layer.
\end{abstract}

Keywords-mobile Internet, entrepreneurship education (EE), education model, entrepreneurship education (EE) platform

\section{Introduction}

In the past few years, the EE for college students has undergone three phases in China: initial exploration, growth, and maturity; and the construction works of college entrepreneurship practice and teaching platforms are deepening constantly $[1,2]$. In China, there're quite a lot of colleges and universities and other higher educational schools all over the country, and their teaching levels vary greatly, it's difficult to realize educational resource fairness, and the models and systems of EE cannot be well popularized and applied [3, 4]. The EE for college students is a powerful impetus for the development of society and economy, it is a significant manifestation of quality education, a valuable means of survival education, and an important component of lifelong education [5, 6]. However, analysis and survey showed that, current college students have some misunderstandings of EE, and they generally lack ideas, spirit, awareness, interest, and confidence of entrepreneurship [7, 8].

Colleges are the frontier for training college students' entrepreneurship, technology and creativity are their main strengths $[9,10]$. Mobile Internet is the most widely used 
platform nationwide. The EE platforms for college students independently built between schools or regions have become the most popular application form $[11,12]$. The mobile Internet environment has restructured the transfer and sharing of knowledge, and its application has become an important carrier for the formation and development of society [13-15]. Based on the universal rules of education, introducing mobile Internet can inject new vitality into the cultivation of college students, in this way, the advantages of Internet technologies could be fully applied to the teaching activities, and the education quality and efficiency could be improved $[16,17]$.

In a mobile Internet environment, college students would have more entrepreneurial opportunities, larger platforms, lower access threshold, and fairer competition [18-20]. The goal of EE is to train entrepreneurs, however, the EE of most colleges and universities carried out in the context of a mobile Internet environment is still limited to some student entrepreneur awards, which is seriously out of touch with the practice of EE [21, 22]. In a mobile Internet environment, the traditional job-hunting ideas are no longer suitable for the employment of college graduates, and such situation has urged colleges and universities to reform their EE for college students, so that they could have more direct experience of entrepreneurship [23, 24]. In such context, this paper tries to analyze the current state of EE for college students based on mobile Internet, and explore the effect of EE for college students in such an environment.

\section{Current state of EE for college students}

\subsection{Problems}

The content of higher education generally focuses on the teaching of certain disciplines. The EE has become an important direction for the research and development of higher education systems in the world [25]. Theoretical knowledge and ideology are no longer the only training goal of ordinary colleges and universities, cultivating creative entrepreneurs and qualified managers has also been listed as one of their training goals [26, 27]. Investigation on students revealed that, compared with social development level, the level of EE in most schools in China is falling behind [28]. Figure 1 summarized problems existing in the EE for college students. First, the cognitive concept of EE for college students is incorrect. Although the schools have made great efforts to implement EE, they haven't put it in a level to power social economy, and they merely stay at trying to increase the employment rate of graduates. Second, the theories and systems of EE in colleges and universities are unfounded and incomplete. Third, the faculty resource for EE is insufficient; teachers lack hands-on experience of starting a business, so their talk is empty. Fourth, the implementation scope of EE is not extensive enough, few schools have implemented it, and the student population who can benefit from EE is very limited. Fifth, the actual effect of EE for college students is not obvious; students generally lack the 
ability to think independently and make correct judgement, therefore, the result of entrepreneurship is often suboptimal.

\begin{tabular}{|c|c|}
\hline $\begin{array}{c}\text { Problems existing } \\
\text { in student } \\
\text { entrepreneurship } \\
\text { education }\end{array}$ & \begin{tabular}{|} 
The cognitive concept of entrepreneurship \\
education for college students is incorrect
\end{tabular} \\
\cline { 2 - 3 } & \begin{tabular}{|} 
The theoretical system of entrepreneurship \\
education for college students is not perfect
\end{tabular} \\
\hline $\begin{array}{c}\text { The teaching staff construction of entrepreneurship } \\
\text { education for college students is not perfect }\end{array}$ \\
\hline $\begin{array}{c}\text { The practical effect of entrepreneurship education } \\
\text { for college students is not obvious }\end{array}$ \\
\hline
\end{tabular}

Fig. 1. Problems existing in EE for college students

Figure 2 explores the causes of the problems listed in Figure 1. First, the traditional teaching concept has hindered the development of EE for college students; the utilitarian ideas seriously affected students' learning effect, in their heart, they do not agree with the content of EE, which has seriously impeded the development and implementation of EE. Second, the traditional education model has hindered the implementation of EE, seriously affected the effect of EE, and discouraged the enthusiasm of college students for EE. Third, the complex social environment has restricted the development of EE for college students. The complex social environment can easily hurt students' confidence in entrepreneurship, once they lose confidence, they will be reluctant to receive EE, and this would also affect the development of EE.

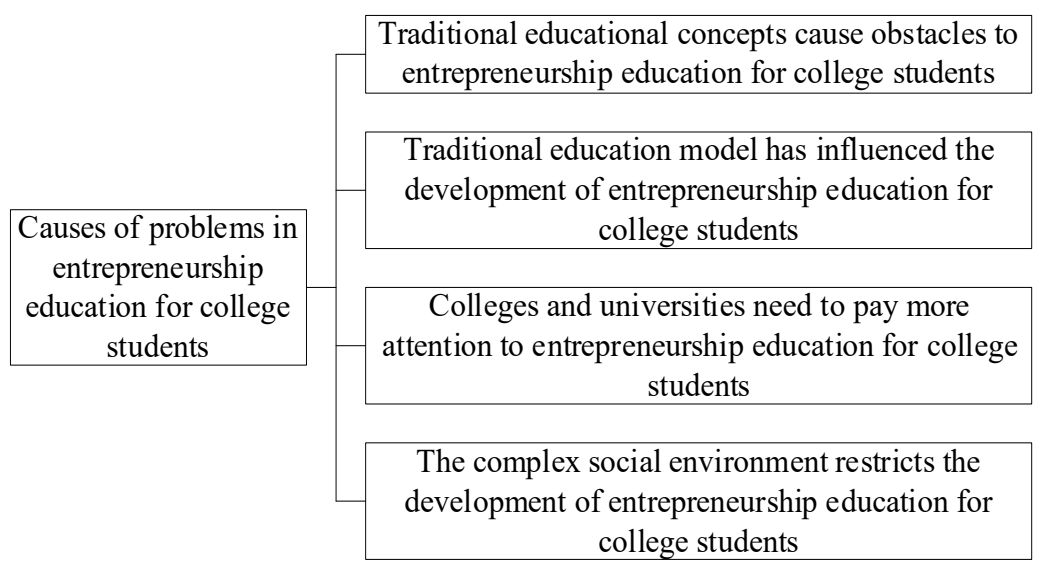

Fig. 2. Causes of problems in EE for college students 


\subsection{Countermeasures}

The EE for college students is part of their careers. It can improve the theory and knowledge systems of EE, build platforms and practice approaches for the entrepreneurship of college graduates, and promote the establishment of the support and service systems for the entrepreneurship of college graduates [29, 30]. Figure 3 proposes a few countermeasures for the EE for college students, including: enrich the content of EE for college students and cultivate their entrepreneurial concepts, spirit, qualities, capabilities, and mentality; build an effective guarantee mechanism for the EE, improve the theory and knowledge systems of EE, build platforms and practice approaches for the entrepreneurship of college graduates, establish support and service systems for the entrepreneurship of college graduates, and optimize the policies, laws, and regulations related to the entrepreneurship of college graduates; implement right approaches of the EE for college students, such as publicity and incentives, classic education methods, consulting service, and group practice, etc.

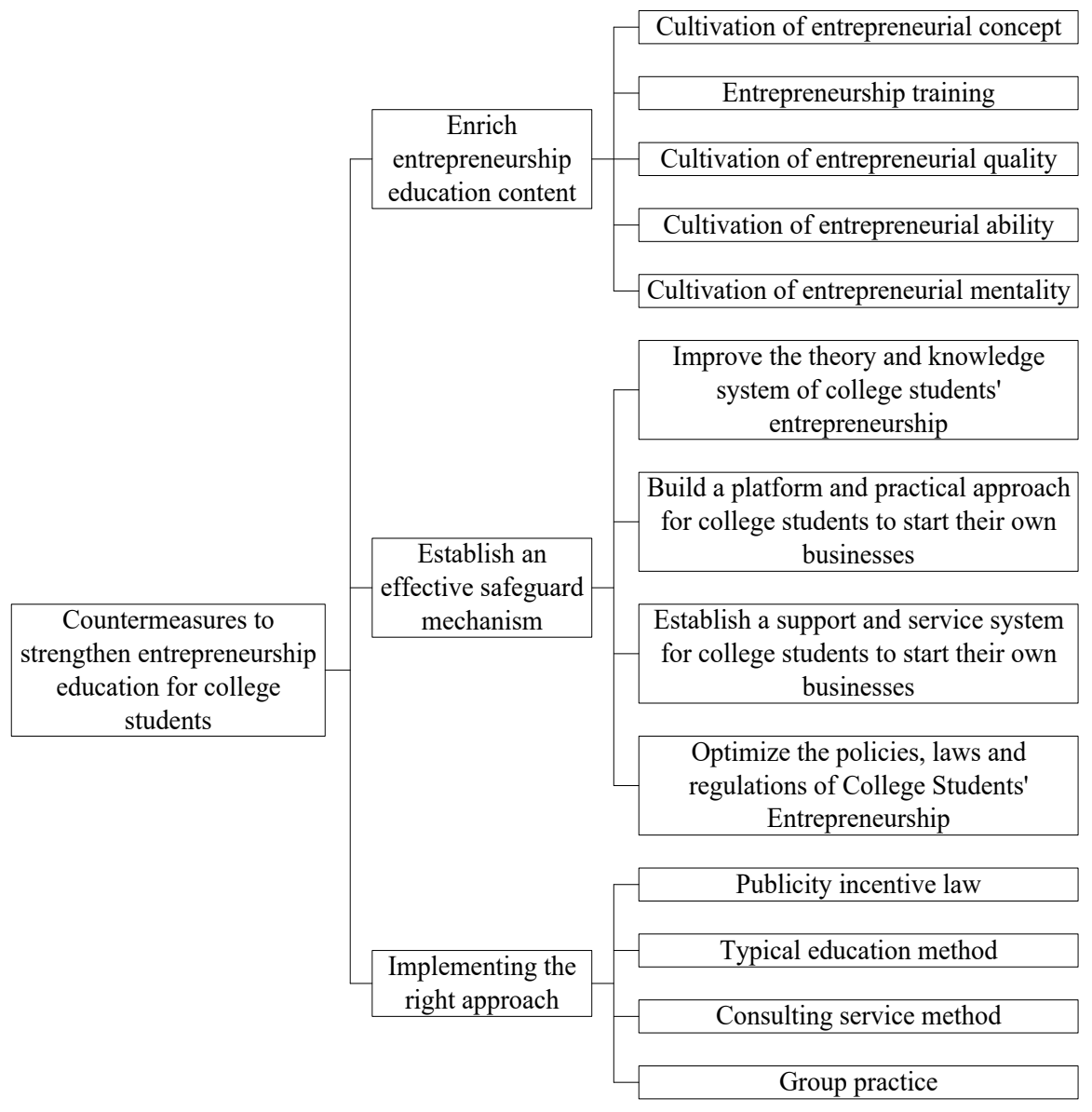

Fig. 3. Countermeasures of the EE for college students 


\section{Current State of EE for College Students Under Mobile Internet}

\subsection{Impact of mobile Internet on EE for college students}

Different students hold different attitudes, ideas, and personal values towards entrepreneurship [31]. The mobile Internet breaks geographical restrictions, it can realize mutual communication, data open, and data flow; and the various resources provided to students by mobile Internet are being expanded continuously [32-34]. Figure 4 shows the impact of mobile Internet on EE for college students. Mobile Internet has greatly enriched the content of EE for college students, provide more convenience for the $\mathrm{EE}$ for college students, promote the equality of $\mathrm{EE}$ for college students, push the innovation of $\mathrm{EE}$ for college students, and improve the environment of EE for college students.

\begin{tabular}{|c|c|}
\hline $\begin{array}{c}\text { The influence of mobile } \\
\text { Internet on college Students' } \\
\text { entrepreneurship education mode for college students }\end{array}$ \\
\hline \begin{tabular}{|c|} 
Mobile Internet provides more convenience for \\
entrepreneurship education for college students
\end{tabular} \\
\hline $\begin{array}{c}\text { Mobile Internet increases the fairness of } \\
\text { entrepreneurship education model for college students }\end{array}$ \\
\hline $\begin{array}{c}\text { Mobile Internet has promoted the innovation of } \\
\text { entrepreneurship education mode for college students }\end{array}$ \\
\hline $\begin{array}{c}\text { Mobile Internet improves the environment of } \\
\text { entrepreneurship education for college students }\end{array}$ \\
\hline
\end{tabular}

Fig. 4. Impact of mobile Internet on EE for college students

Figure 5 lists problems in the application of the education model. The knowledge system of EE is inadequate, and there's few contents about value orientation; there're too many simulated entrepreneurship software, especially business simulation software, however, few of the platforms can run through the entire teaching process. The resource of EE platforms is insufficient, the functions are quite limited, neither sharing nor interactive; the implementation of the projects mostly stays at the planning stage, the teaching methods are not proper, and the main difficulty of teaching reform lies in the too few teaching designs that can stimulate innovative thinking. Figure 6 lists problems in EE for college students under mobile Internet:

First, college students generally have a weak awareness for entrepreneurship, they are not interested in it, and their attitude is negative;

Second, in current EE, the content of professional knowledge or skills is too few;

Third, college students' entrepreneurial requirements could not be met;

Fourth, current entrepreneurial education in colleges and universities stays at a low level; 
Fifth, only a small number of students have participated in entrepreneurial activities, and the conversion rate of obtained results is low;

Sixth, the management of EE in colleges and universities is not good.

\begin{tabular}{|c|c|}
\hline $\begin{array}{c}\text { Knowledge system of innovation and entrepreneurship } \\
\text { education is insufficient }\end{array}$ \\
\hline $\begin{array}{c}\text { The problems existing in } \\
\text { the application of } \\
\text { teaching mode in the } \\
\text { platform }\end{array}$ & $\begin{array}{c}\text { There are too many entrepreneurial simulation software, } \\
\text { and there are few platforms to implement the whole } \\
\text { teaching process }\end{array}$ \\
\hline $\begin{array}{c}\text { Innovation and entrepreneurship education platform has } \\
\text { insufficient resources, poor interaction and limited } \\
\text { function }\end{array}$ \\
\hline Project implementation is mostly in the planning stage \\
\hline Too few instructional designs stimulate creative thinking \\
activities
\end{tabular}

Fig. 5. Problems in the application of education model

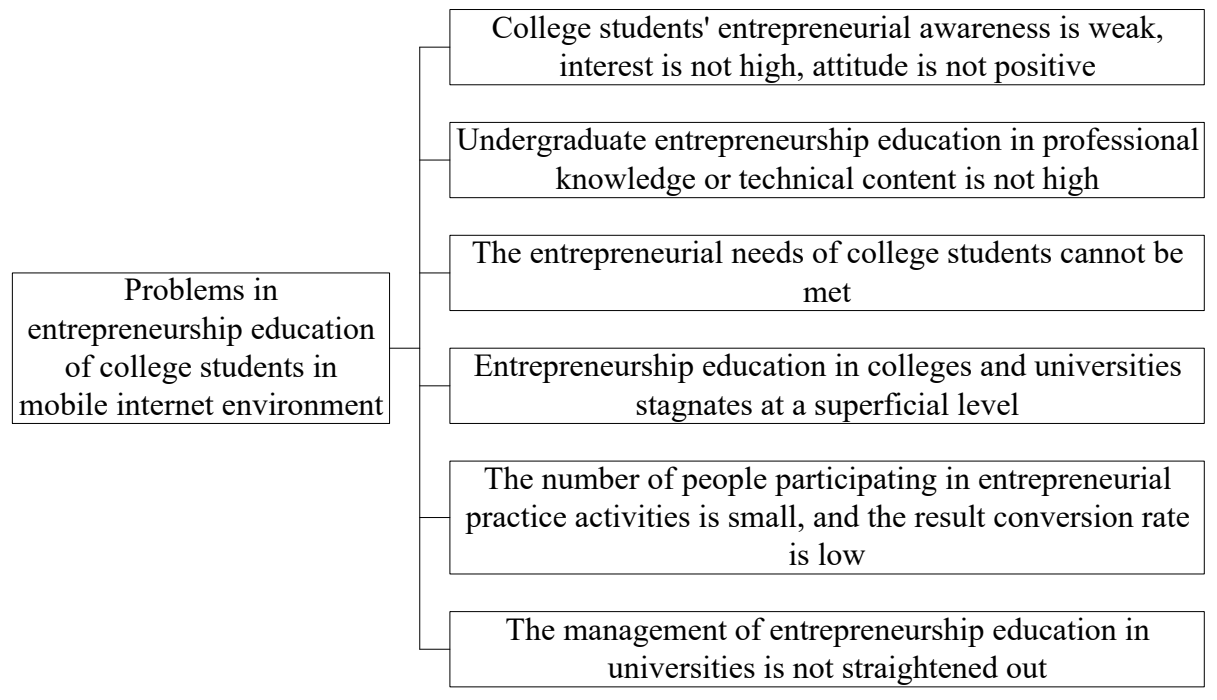

Fig. 6. Problems in EE for college students under mobile Internet

\subsection{Strategies}

Many factors can affect the EE for college students in the mobile Internet environment. Figure 7 lists a few strategies for improving the EE for college students in 
the mobile Internet environment. The strategies are proposed from several perspectives, including the individual college student's perspective, the higher educational school's perspective, the macroscopical social perspective, and the online entrepreneurship course's perspective. First, in terms of individual students, they need to change their traditional employment ideas, develop a sense of self-employment; actively participate in entrepreneurship training, enhance their entrepreneurial capabilities; and rely on local characteristics to give full play to the advantages of entrepreneurship in local areas. In terms of schools, ordinary colleges and universities should establish a complete EE curriculum system and strengthen their faculties; the schools need to transform students' traditional employment ideas, construct "Internet \& entrepreneurship" higher educational schools, and strengthen the construction of entrepreneurship bases. In terms of the society, risk funds could be set up to help reducing entrepreneurial risks; entrepreneurial culture should be created and innovation and entrepreneurship should be encouraged; also, local regulations should be formulated to provide guarantee for entrepreneurship. In terms of entrepreneurship courses, in the context of mobile Internet, every college student should enhance their computer operation ability; as for the assessment of EE courses, the ultimate goal is not to increase exam pressure on students, but to offer real help to the entrepreneurship of college graduates.

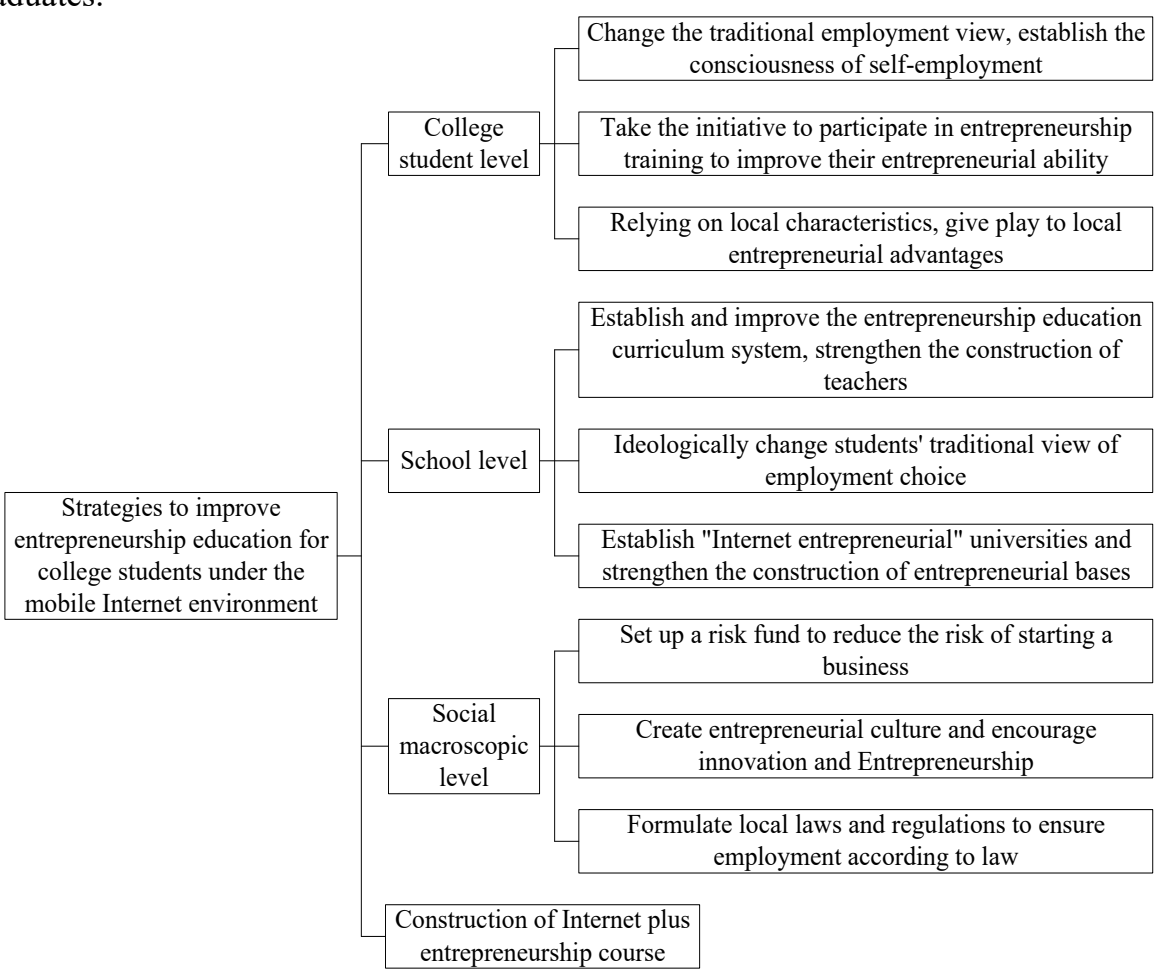

Fig. 7. Strategies for improving the EE for college students in the mobile Internet environment. 


\section{Effect of EE for College Students under Mobile Internet}

\subsection{Model design}

In a mobile Internet environment, the model of EE for college students pays more attention to two links: learning and practice. Figure 8 shows the design principles of the model of EE for college students, which include: establishing learning modes that emphasize cultivating students' abilities and developing their personalities; taking learners as subjects to enhance the process of learning connection; applying mobile Internet to the model design process of EE for college students and strengthening the connection among active learning, independent learning, and hands-on practice; making use of the mobile Internet to realize the sharing of learning resources and the innovation of learning tools and methods, and establishing a knowledge network system; well instructing the teaching process of teachers, comprehensively improving students' abilities and qualities, and adopting multiple mechanisms to evaluate the teaching process.

\begin{tabular}{|c|c|}
\hline & $\begin{array}{l}\text { The learning mode of "cultivating students' ability" and "attaching } \\
\text { importance to students' personalized development" should be } \\
\text { established to realize the construction of personalized knowledge } \\
\text { and the improvement of innovation ability }\end{array}$ \\
\hline & $\begin{array}{l}\text { Take learners as the main body and enhance the process of } \\
\text { learning connection }\end{array}$ \\
\hline \multirow[t]{3}{*}{$\begin{array}{c}\text { Design principle of } \\
\text { entrepreneurship } \\
\text { education teaching } \\
\text { mode }\end{array}$} & $\begin{array}{l}\text { Mobile Internet is used to realize the sharing and co construction } \\
\text { of learning resources, the innovation of learning tools and means, } \\
\text { and the establishment of knowledge network system }\end{array}$ \\
\hline & $\begin{array}{l}\text { Do a good job in the teaching guidance process of teachers and } \\
\text { comprehensively improve students' ability and quality }\end{array}$ \\
\hline & Adopt diversified teaching evaluation mechanism \\
\hline
\end{tabular}

Fig. 8. Design principles of the model of EE for college students

To figure out the advantages of the model of EE for college students in the mobile Internet environment, a few college students in Shanxi Province, China, were invited to participate in a questionnaire survey. There's no limitation on the discipline of the respondents, both science students and liberal arts students were covered in the survey. Figure 9 shows the statistics on college students' entrepreneurial motivations. According to the survey results, it's obvious that they generally take entrepreneurship as a guarantee of life and a manifestation of their decision-making power. Overall, the students have clear value demands for EE and they have an objective understanding of entrepreneurship. Figure 10 shows the statistics on college students' entrepreneurial abilities. Apparently, their abilities in interpersonal coordination, teamwork, and 
integrity are better. More than half of the college students believe that an energetic person with teamwork spirit is positive and trustworthy.

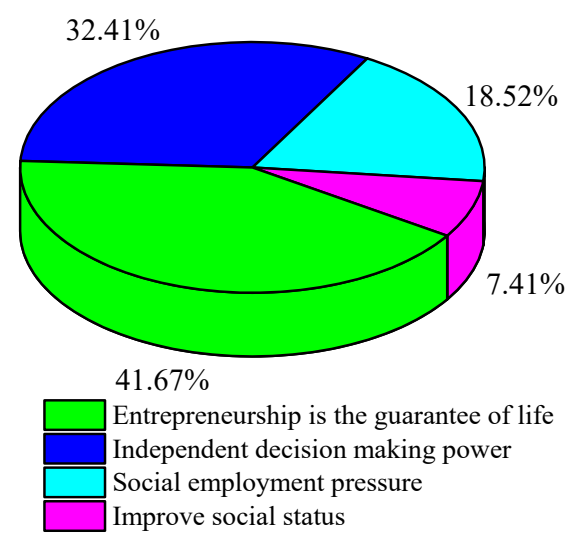

Fig. 9. Statistics on college students' entrepreneurial motivations

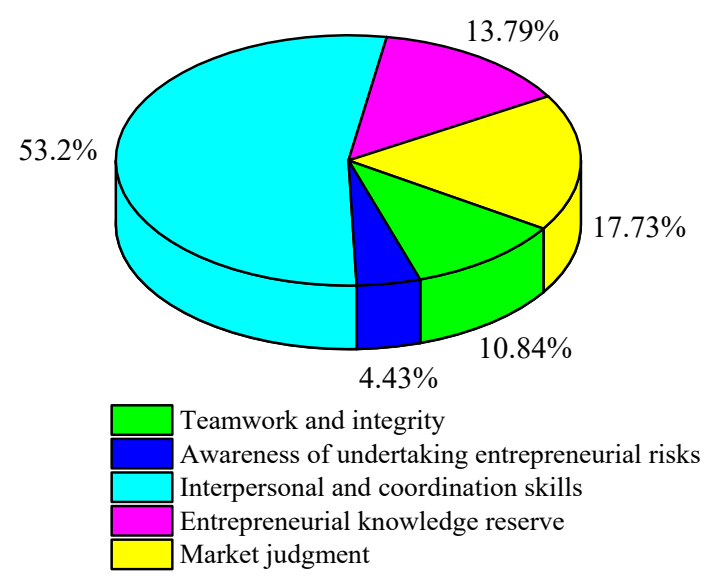

Fig. 10.Statistics on college students' entrepreneurial abilities

\subsection{Design and implementation of online platform of EE for college students}

College students need to change their traditional employment ideas, actively develop entrepreneurial spirit, make efforts to find the right career for themselves, and formulate a good career plan. Some scholars analyzed the big data of Internet entrepreneurship and found that the enterprises that are succeed in Internet entrepreneurship reached the peak value in 2015 and then showed a minor decrease in recent years. Figure 11 shows the statistics on the requirements of students of different grades for EE platform. Data analysis clearly indicated that, more than $90 \%$ of the students believe that establishing a platform with rich experience in teambuilding, teaching, competition, and consultation is very helpful for the development 
of EE for college students. Through preliminary design and investigation, it's found that a platform of EE for college students mainly contains the mobile Internet + consultation module, the teaching module, the sharing module, the team module, and the project module, etc. The consultation module of the platform could provide relevant information and policy notifications and share the resources; the teaching module could display entrepreneurial theory courses, Internet technology courses, and practical courses, etc.; the sharing module could give excellent cases, results, and experiences. Figure 12 shows the architecture of the EE platform for college students, which includes three layers: a data access layer, a business logic layer, and a user interface layer.

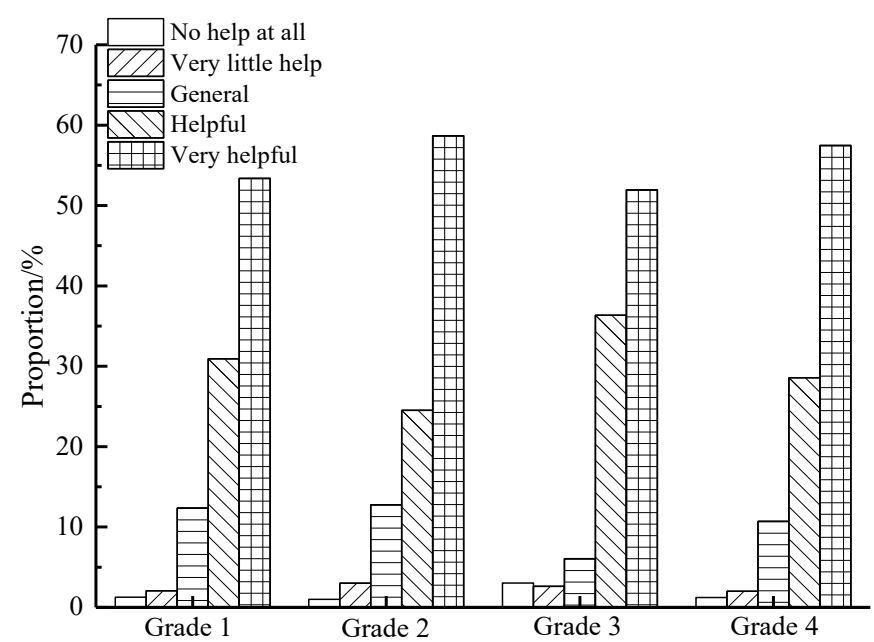

Fig. 11.Statistics on the requirements of students of different grades for EE platform

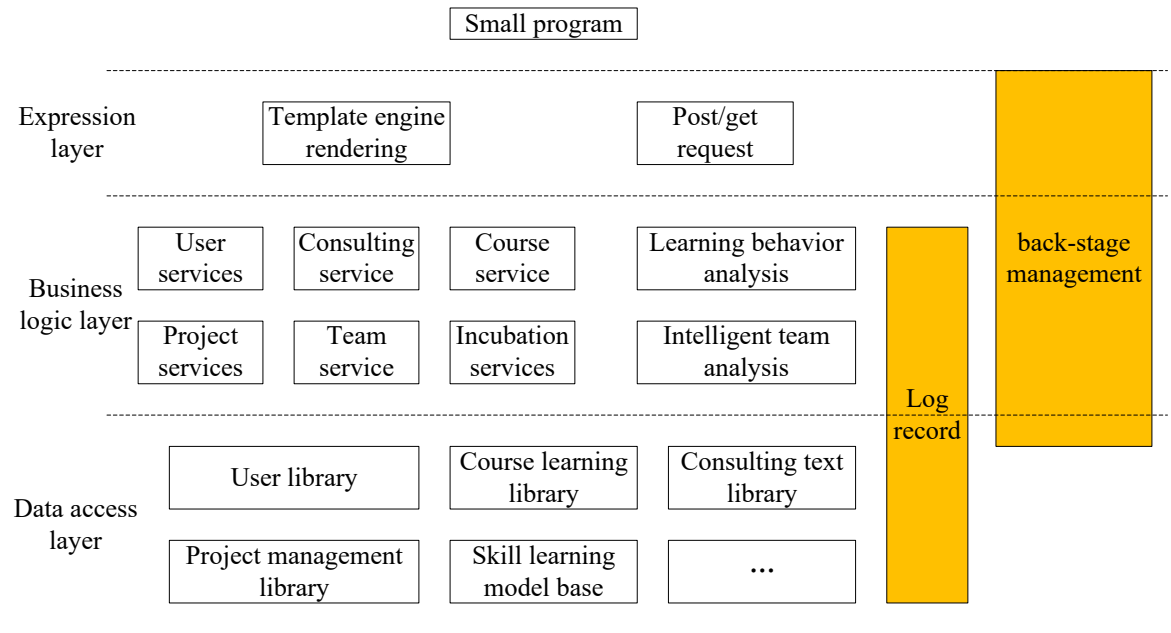

Fig. 12.Architecture of EE platform for college students 


\section{Conclusion}

Based on mobile Internet, this paper analyzed the current state of EE for college students in China, and explored the effect of EE for college students. The specific conclusions are as follows:

1. To improve the effect of EE for college students, this paper proposed a few countermeasures, including: build an effective guarantee mechanism for the EE, improve the theory and knowledge systems of EE, build platforms and practice approaches for the entrepreneurship of college graduates, establish support and service systems for the entrepreneurship of college graduates, and optimize the policies, laws, and regulations related to the entrepreneurship of college graduates.

2. Regarding the assessment of EE courses, the ultimate goal is not to increase exam pressure on students, but to offer real help to the entrepreneurship of college graduates.

3. The architecture of EE platform for college students includes three layers: a data access layer, a business logic layer, and a user interface layer.

\section{References}

[1] Liu, Y. (2020). Interactive system design of entrepreneurship education based on internet of things and machine learning. Journal of Intelligent and Fuzzy Systems, 39(4): 57615772. https://doi.org/10.3233/jifs-189053

[2] Dong, D., Wang, X. (2020). Human-computer system design of entrepreneurship education based on artificial intelligence and image feature retrieval. Journal of Intelligent and Fuzzy Systems, 39(4): 5927-5939. https://doi.org/10.3233/jifs-189067

[3] Daly, S.P. (2001). Student-operated internet businesses: true experiential learning in entrepreneurship and retail management. Journal of Marketing Education, 23(3): 204-215. https://doi.org/10.1177/0273475301233006

[4] Sun, D., Li, S., Xu, X. (2020). Analysis of reform and development strategies of china's internet innovation and entrepreneurship education. Entrepreneurship Education, 3(1): 7793. https://doi.org/10.1007/s41959-020-00024-6

[5] Bureau, S., Salvador, E., Fendt, J. (2012). Small firms and the growth stage: can entrepreneurship education programmes be supportive? Industry \& Higher Education, 26(2): 79-100. https://doi.org/10.5367/ihe.2012.0085

[6] Wu, Y., Kuo, T., Shen, J.P. (2013). Exploring social entrepreneurship education from a web-based pedagogical perspective. Computers in Human Behavior, 29(2): 329-334. https://doi.org/10.1016/j.chb.2012.08.012

[7] Hsieh, Y. J., Wu, Y. J. (2019). Entrepreneurship through the platform strategy in the digital era: insights and research opportunities. Computers in Human Behavior, 95: 315 323. https://doi.org/10.1016/j.chb.2018.03.033

[8] Matlay, H., Iacobucci, D., Micozzi, A. (2012). Entrepreneurship education in italian universities: trend, situation and opportunities. Working Papers, 54(8/9): 673-696. https://doi.org/10.1108/00400911211274828

[9] Khan, E. (2012). Education for the base of the pyramid people (bop) using voice internet e-learning. Procedia - Social and Behavioral Sciences, 64(64): 474-483. https://doi.org/10. $\underline{1016 / \text { j.sbspro.2012.11.056 }}$ 
Paper-Effect of Entrepreneurship Education for College Students in the Context of a Mobile Internet...

[10] Huang, X., Li, X., Yu, Y., Zheng, X., Xu, X. (2019). Integration of bricolage and institutional entrepreneurship for internet finance: alibaba's yu'e bao. Journal of Global Information Management, 27(2): 1-23. https://doi.org/10.4018/jgim.2019040101

[11] Ysb, A., Ssa, B., Aa, C. (2019). A review of digital brand positioning strategies of internet entrepreneurship in the context of virtual organizations: Facebook, instagram and youtube samples. Procedia Computer Science, 158: 513-522. https://doi.org/10.1016/j.procs. 2019.09.083

[12] Lin, Z., Zhang, Z., Liu, Y. (2018). Self as enterprise: digital disability practices of entrepreneurship and employment in the wave of 'internet+disability' in china. Information Communication and Society, 22: 554-569. https://doi.org/10.1080/1369118x.2018. 1518470

[13] Shao, Y., Wu, T., Qiu, H., Wang, Z. (2018). Ambidextrous activities of internet-based entrepreneurships in apple app store: two sides of user feedback. Technology Analysis and Strategic Management, 30(10): 1210-1225. https://doi.org/10.1080/09537325.2018. $\underline{1458980}$

[14] Reuber, A.R., Fischer, E. (2011). International entrepreneurship in internet-enabled markets. Journal of Business Venturing, 26(6): 660-679. https://doi.org/10.1016/j.jbusvent. $\underline{2011.05 .002}$

[15] Cumming, D., Johan, S. (2010). The differential impact of the internet on spurring regional entrepreneurship. Entrepreneurship Theory and Practice, 34(5): 857-883. https://doi.org/ $10.1111 / \mathrm{j} .1540-6520.2009 .00348 . \mathrm{x}$

[16] Batjargal, B. (2007). Internet entrepreneurship: social capital, human capital, and performance of internet ventures in china. Research Policy, 36(5): 605-618. https://doi. org/10.1016/j.respol.2006.09.029

[17] Pierluigi, R., Giustina, S. (2018). Digital academic entrepreneurship: the potential of digital technologies on academic entrepreneurship. Technological Forecasting and Social Change, 146: 900-911. https://doi.org/10.1016/j.techfore.2018.07.013

[18] Obschonka, M., Zhou, M., Zhou, Y., Zhang, J., Silbereisen, R.K. (2018). "confucian" traits, entrepreneurial personality, and entrepreneurship in china: a regional analysis. Small Business Economics, 53(4): 961-979. https://doi.org/10.1007/s11187-018-0103-8

[19] Liu, H., Kulturel-Konak, S., Konak, A. (2021). A measurement model of entrepreneurship education effectiveness based on methodological triangulation. Studies In Educational Evaluation, 70(5): 100987. https://doi.org/10.1016/j.stueduc.2021.100987

[20] Ding, Y.Y. (2017). The constraints of innovation and entrepreneurship education for university students. Journal of Interdisciplinary Mathematics, 20(6-7): 1431-1434. https://doi.org/10.1080/09720502.2017.1382152

[21] Cui, J., Sun, J., Bell, R. (2019). The impact of entrepreneurship education on the entrepreneurial mindset of college students in china: the mediating role of inspiration and the role of educational attributes. The International Journal of Management Education, 19(1): 100296. https://doi.org/10.1016/j.ijme.2019.04.001

[22] Krishnan, K., Wang, P. (2019). The Cost of Financing Education: Can Student Debt Hinder Entrepreneurship? Management Science, 65(10): 4522-4554. https://doi.org/10. $\underline{1287 / \mathrm{mnsc} .2017 .2995}$

[23] Wu, Y., Wu, T., Li, Y. (2019). Impact of using classroom response systems on students' entrepreneurship learning experience. Computers in Human Behavior, 92: 634-645. https://doi.org/10.1016/j.chb.2017.08.013

[24] Matlay, H., Belwal, R., Balushi, H.A., Belwal, S. (2015). Students' perception of entrepreneurship and enterprise education in oman. Education \& Training, 57(8-9): 924-947. https://doi.org/10.1108/et-12-2014-0149 
Paper-Effect of Entrepreneurship Education for College Students in the Context of a Mobile Internet...

[25] Salisu, J.B. (2020). Entrepreneurial training effectiveness, government entrepreneurial supports and venturing of tvet students into it related entrepreneurship - an indirect-path effects analysis. Heliyon, 6(11): e05504. https://doi.org/10.1016/j.heliyon.2020.e05504

[26] Westhead, P., Solesvik, M. Z. (2015). Entrepreneurship education and entrepreneurial intention: do female students benefit? International Small Business Journal, 34(8): 9791003. https://doi.org/10.1177/0266242615612534

[27] Bandera, C., Collins, R. Passerini, K. (2018). Risky business: experiential learning, information and communications technology, and risk-taking attitudes in entrepreneurship education. International Journal of Management Education, 16(2): 224-238. https://doi.org/ $\underline{0.1016 / j . j i m e .2018 .02 .006}$

[28] Din, B.H., Anuar, A.R., Usman, M. (2016). The effectiveness of the entrepreneurship education program in upgrading entrepreneurial skills among public university students. Procedia - Social and Behavioral Sciences, 224: 117-123. https://doi.org/10.1016/j.sbspro. 2016.05.413

[29] Thomson, G.S., Minhas, W. (2017). Enabling entrepreneurship: entrepreneurial intentions among emirati students. Journal of Enterprising Culture, 25(2): 211-237. https://doi.org/10. $1142 / \mathrm{s} 021849581750008 \mathrm{x}$

[30] Oosterbeek, H., Praag, M.V., Ijsselstein, A. (2009). The impact of entrepreneurship education on entrepreneurship skills and motivation. Social Science Electronic Publishing, 54(3): 442-454. https://doi.org/10.1016/j.euroecorev.2009.08.002

[31] Matlay, H., Hytti, U., Stenholm, P., Heinonen, J., Seikkula-Leino, J. (2010). Perceived learning outcomes in entrepreneurship education: the impact of student motivation and team behaviour. Education \& Training, 52(8-9): 587-606. https://doi.org/10.1108/ $\underline{00400911011088935}$

[32] Li, K., Zhang, G.H., Li, N., Yang, H. (2019). A novel public information system for mobile geriatric medical services. Revue d'Intelligence Artificielle, 33(3): 197-202. https://doi.org/10.18280/ria.330305

[33] Chigozirim, A., Vivian, N.O., Uchenna, N.J., Oreoluwa, A.A. (2020). A patient monitoring system using internet of things technology. Ingénierie des Systèmes d'Information, 25(3): 351-357. https://doi.org/10.18280/isi.250309

[34] Fenanir, S., Semchedine, F., Baadache, A. (2019). A machine learning-based lightweight intrusion detection system for the internet of things. Revue d'Intelligence Artificielle, 33(3): 203-211. https://doi.org/10.18280/ria.330306

\section{$7 \quad$ Authors}

Dapeng Sun, currently an associate professor of Hebei Institute of Mechanical and Electrical Technology, graduated from Jilin Agricultural University. His research direction is vocational education and innovation and entrepreneurship education. 15 papers have been published. Email: c603971@163.com.

Mengnan Li born in Langfang, Hebei province in September 1979, master of Management, Beijing Normal University. Now, she works as a lecturer in the Academic Affairs Office of North China Institute of Aerospace Engineering. A total of 10 papers have been published, including 2 core journal. She mainly participated in 9 research projects. Chief editor of 2 monographs.

Article submitted 2021-08-25. Resubmitted 2021-09-28. Final acceptance 2021-09-28. Final version published as submitted by the authors. 